\title{
Aspects on gametogenesis, fertilization and embryogenesis of two deep-sea polychaetes from Eastern Atlantic cold seeps
}

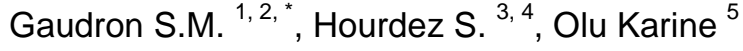

${ }^{1}$ CNRS, Univ. Lille, Univ. Littoral Côte d'Opale, UMR 8187, LOG, Laboratoire d'Océanologie et de Géosciences, F 62930 Wimereux, France

${ }^{2}$ Sorbonne Universités, Université Pierre et Marie Curie Paris 06, UFR 927, 4 place Jussieu, 75005

Paris, France

${ }^{3}$ Sorbonne Universités, UPMC Univ Paris 06, UMR 7144, Equipe ABICE, Station Biologique de

Roscoff, 29680 Roscoff, France

${ }^{4}$ CNRS, UMR 7144, Adaptation et Diversité en Milieu Marin, Station Biologique de Roscoff, 29680

Roscoff, France

${ }^{5}$ IFREMER Centre Bretagne, Laboratoire Environnement Profond, Plouzané, France

* Corresponding author : S.M. Gaudron, email address : sylvie.gaudron@upmc.fr

\begin{abstract}
:
We investigated two gonochoristic species of annelid polychaetes (one siboglinid and one polynoid) from cold seeps that ranged from $525 \mathrm{~m}$ to $3300 \mathrm{~m}$ in depth (Guiness, Worm Hole and Regab pockmarks) on the Gabon and Congo continental margins (Gulf of Guinea). Different aspects of gametogenesis (oocyte diameter, presence of ovisac, spermatozoa shape, and fecundity), fertilization (in vitro fertilization experiments: IVF) and embryogenesis (cleavage rate) were studied. The sampled siboglinid was a new species of Lamellibrachia and the second population of this genus in the Eastern Atlantic. Mean oocyte diameter was about $100 \mu \mathrm{m}$ and fully-grown primary oocytes were stored in an ovisac, as in other studied siboglinids. The presence of a single spermatozoon was noted within an oviduct, indicating a possible internal fertilization. The rate of cell division at $6{ }^{\circ} \mathrm{C}$ was one cleavage every $20 \mathrm{~h}$. Embryos developed normally to the blastula stage after 5-d post-fertilization at atmospheric pressure suggesting some pressure tolerance. The second polychaete was the scale-worm Branchipolynoe cf. seepensis that lives in commensalism in the mantle cavity of Bathymodiolus aff. boomerang. Anatomical reproductive features were similar to those described in $B$. seepensis from hydrothermal vents on Mid-Atlantic Ridge, with lecithotrophic larval development and continuous gametogenesis. We performed the first IVF carried out on gametes for any deep-sea polynoid species. Fertilization and development occurred but a number of abnormalities were observed demonstrating a limitation to embryogenesis at atmospheric pressure. The rate of cell division was three times faster at $8{ }^{\circ} \mathrm{C}$ than at $4{ }^{\circ} \mathrm{C}$ with a maximum stage of 8 -cells reached after $72 \mathrm{~h}$ post-fertilization. We surprisingly observed some oocytes from the negative seawater control during IVF experiments cleaved to the 2-cell stage, demonstrating the possible occurrence of internal fertilization prior to IVF experiment or the accidental release of sperm from the female's spermatheca.
\end{abstract}




\section{Highlights}

- Reproduction and development of a new species Lamellibrachia sp. 'Guiness', a deep-sea cold seeps polychaete was investigated. Reproduction and development of a population of Branchipolynoe cf. seepensis was investigated in a deep-sea cold seeps. For the first time an in vitro fertilization experiment was carried out on gametes for a deep-sea polynoid species. Lamellibrachia sp. 'Guiness' embryos are pressure-tolerant.

Keywords : Branchipolynoe, cold seeps, dispersal, Lamellibrachia, polynoid, reproduction, siboglinid 


\section{Introduction}

Deep-sea ecosystems are under anthropogenic pressure such as deep-sea mining in hydrothermal vents habitats, or, as oil drilling in continental margins (e.g. in cold seeps) increasing risks of oil spillage (Ramirez-Llodra et al. 2011; Thurber et al. 2014). Hydrothermal vents and cold seeps host specialized endemic fauna that have a bentho-pelagic life cycle. Adults are limited in their dispersal capacity, and often attached to the substrate, and dispersal occurs only through the larval stage. These rise into the water column and are able to disperse over long distances from their site of origin. In some cases, a pool of larvae may be retained near the site of origin (Young et al. 2012; Mullineaux et al. 2013). Moreover these deep-sea chemosynthetic-based ecosystems are fragmented and ephemeral (but on different time scales depending on fluid emission and geological settings) which may increase the complexity of detection of suitable habitats by a metazoan larva for its colonization and for the persistence of the species. One solution to minimize the impact of deep-sea activities on deep-sea populations is to create networks of Marine Protected Areas (MPAs) that would harbour populations for reproduction and maintain gene flow between populations (connectivity; Cowen and Sponaugle 2009). To establish MPAs, one key piece of knowledge is an understanding of the dispersal of a target species by a mean for example of a biophysical model that would help predicting, with knowledge of oceanic currents, where a propagule 


\section{ACCEPTED MANUSCRIPT}

(embryo, larva) could disperse in the water column (Hilário et al. 2015). This will indirectly give information on where MPAs should be implanted to be most effective. However, our knowledge of life cycles in the deep sea remains limited and no complete metazoan species life cycle is well understood to date (Tyler and Young 1999). To establish a biophysical model some key biological characters on reproduction and development of a species are needed, such as the spawning site, spawning period, fecundity, pelagic larval duration (PLD), embryo buoyancy, larval velocity and larval tolerance to temperature and pressure.

Annelid polychaetes are one of the major taxa that make up metazoan diversity at hydrothermal vents and cold seeps (Mullineaux et al. 2003; Ritt et al. 2011). These taxa are of ecological importance, with species such as siboglinid tubeworms considered to be ecosystem engineers (Cordes et al. 2003; Govenar 2010), and contribute to different trophic levels in a vent food web (Levesque et al. 2006; Bergquist et al. 2007). To date, thirteen hydrothermal vent species from the families Siboglinidae, Alvinellidae, Polynoidae, and Ampharetidae have been studied for reproduction (Van Dover et al. 1999; review Tyler \& Young 1999; Jollivet et al. 2000; Glover et al. 2005; Hilário et al. 2005; Southward et al. 2011). At cold seeps, the reproduction of only 7 species has been studied to date, and these belong to two families (Siboglinidae and Hesionidae). As far as embryogenesis is concerned, only Riftia pachyptila (Marsh et al. 2001; Brooke and Young 2009) and Alvinella pompejana (Pradillon et al. 2001; 2005) have been studied at hydrothermal vents. For cold seeps, 4 species have been studied, including Lamellibrachia luymesi and Seepiophila jonesi (Young et al. 1996), L. satsuma (Miyake et al. 2006) and Hesiocaeca methanicola (Eckelbarger et al. 2001). In a recent synthesis on PLD, Hilário et al. (2015) reported those of only four deep-sea annelid polychaetes.

The reproductive biology and development of the symbiotic vestimentiferan tubeworms (family Siboglinidae) is currently the best studied. However most studies were performed on species from hydrothermal vents and cold seeps from the Pacific and from the Gulf of Mexico (Western Atlantic) (see reviews Tyler and Young 1999; Bright and Lallier 2010). No reproductive studies and embryogenesis have so far been carried out on vestimentiferan siboglinid species from the Eastern Atlantic, Mediterranean or Indian Ocean. These tubeworms lack a digestive tract at the adult stage and solely rely on endosymbiotic bacteria for nutrition. These bacteria are hosted inside a unique organ called the trophosome (Bright and Lallier 2010). The genus Lamellibrachia lives in aggregations where sulphide supply is enough to sustain their symbiotic chemosynthetic bacteria (Cordes et al. 2003). In our study, 


\section{ACCEPTED MANUSCRIPT}

a new species of Lamellibrachia was found on authigenic carbonate at hydrocarbon cold seeps located on the continental margin of Western Africa in the Gulf of Guinea. This was the second time that this genus has been found in the Eastern Atlantic, where Lamellibrachia sp. has been collected from a shipwreck at $1160 \mathrm{~m}$ depth on the Northern coast of Spain (Dando et al. 1992). To date, only the siboglinid Escarpia southwardae has been studied in the Gulf of Guinea (Andersen et al. 2004).

Lamellibrachia spp. are dioceous, females have generally high fecundity and reproduce continuously (Young 2003; Hilário et al. 2005). The larvae are generally lecithotrophic (Young et al. 1996). Using data on ocean circulation with a Lagrangian larval transport model, Young et al. (2012) modelled the potential dispersal of offspring from L. luymesi from cold seeps of the Gulf of Mexico using a PLD of 21 days with positively and then neutrally buoyant eggs. The maximum dispersal kernel reached $300 \mathrm{~km}$, with a mean dispersal distance of $\sim 100 \mathrm{~km}$. For this study however, the PLD was calculated under the assumption that the larvae were lecithotrophic. Miyake et al. (2006) estimated a PLD of 45 days for L. satsuma and hypothesized that the larvae could disperse up to thousands of kilometers. The dispersal potential of Lamellibrachia spp. larvae is still not completely understood. For instance, $L$. anaximandri (Southward et al. 2011) inhabits cold seeps sites ranging from the Eastern Mediterranean to the Strait of Sicily (Rubin-Blum et al. 2014), separated by $1800 \mathrm{~km}$. One specimen of Lamellibrachia sp. has been molecularly identified based on the COI gene (Hilário et al. 2011) in the Western Mediterranean, similar to those from Eastern Mediterranean described by Southward et al. (2011).

The reproductive biology of deep-sea polynoids has been studied in three species from hydrothermal vents and whale carcasses (Van Dover et al. 1999; Jollivet et al. 2000; Glover et al. 2005). The commensal scale-worm Branchipolynoe seepensis that lives inside the pallial cavity of different species of Bathymodiolus spp. (Britayev et al. 2007) was among the studied species. Reproduction has been well studied in populations of B. seepensis from hydrothermal vents from the Mid-Atlantic Ridge (MAR) (Van Dover et al. 1999; Jollivet et al. 2000). This species is dioceous, with a moderate fecundity and with continuous reproduction. No study was performed on the embryogenesis and larval development in that species, however very large fully-grown oocyte size $(\sim 300-400 \mu \mathrm{m})$ was reported, likely indicating lecithotrophic larvae (Jollivet et al. 2000). Branchipolynoe seepensis seems to have a very large distribution, ranging from seeps in the Gulf of Mexico in the Western Atlantic to hydrothermal vents on the MAR, although this corresponds to a species complex (S. Hourdez, unpublished data). 


\section{ACCEPTED MANUSCRIPT}

Studies so far have focused on the population genetics of the MAR species (Jollivet et al. 1998; Daguin and Jollivet 2005; Plouviez et al. 2008). The results indicate a fairly large potential dispersal, with probable local retention as well. In our study, we worked with an unstudied population of B. seepensis that were recovered from the mantle cavity of Bathymodiolus aff. boomerang (Cosel \& Olu 1998; Olu-Le Roy et al. 2007a) collected at cold seeps on the continental margin of Western Africa. This species is hereafter referred to as $B$. cf. seepensis.

This article aims to shed light on key life history traits (gametogenesis, fecundity, fertilization and embryogenesis) of two deep-sea polychaete species from cold seep habitats. This will contribute to increase the fundamental knowledge on life-history patterns of deep-sea species that are still scarce.

\section{Materials and Methods}

\subsection{Sample collection}

The two annelids species studied here were collected at cold seeps (Fig. 1) in the Eastern Atlantic, on the West coast of Africa (Gulf of Guinea) during the WACS ('West African Cold Seeps') cruise aboard RV Pourquoi Pas? using the ROV Victor 6000 in February 2011 (Olu, 2011). The three distinct sites visited are all pockmarks resulting from fluid expulsion, where bathymodiolin and siboglinids are associated with methane-derived carbonates (Ondréas et al. 2005; Pierre \& Fouquet 2007). While the Regab and Worm Hole pockmarks are located at about $3100 \mathrm{~m}$ depth not far from the Congo channel (Fig. 1), the Guiness area is at about 600 $m$ depth on the Gabon margin. For more details on site descriptions, see Olu-Le Roy et al. (2007b) for the Regab pockmark, Sahling et al. (2008) for Worm Hole pockmark and Duperron et al. (2012) for the Guiness site. 


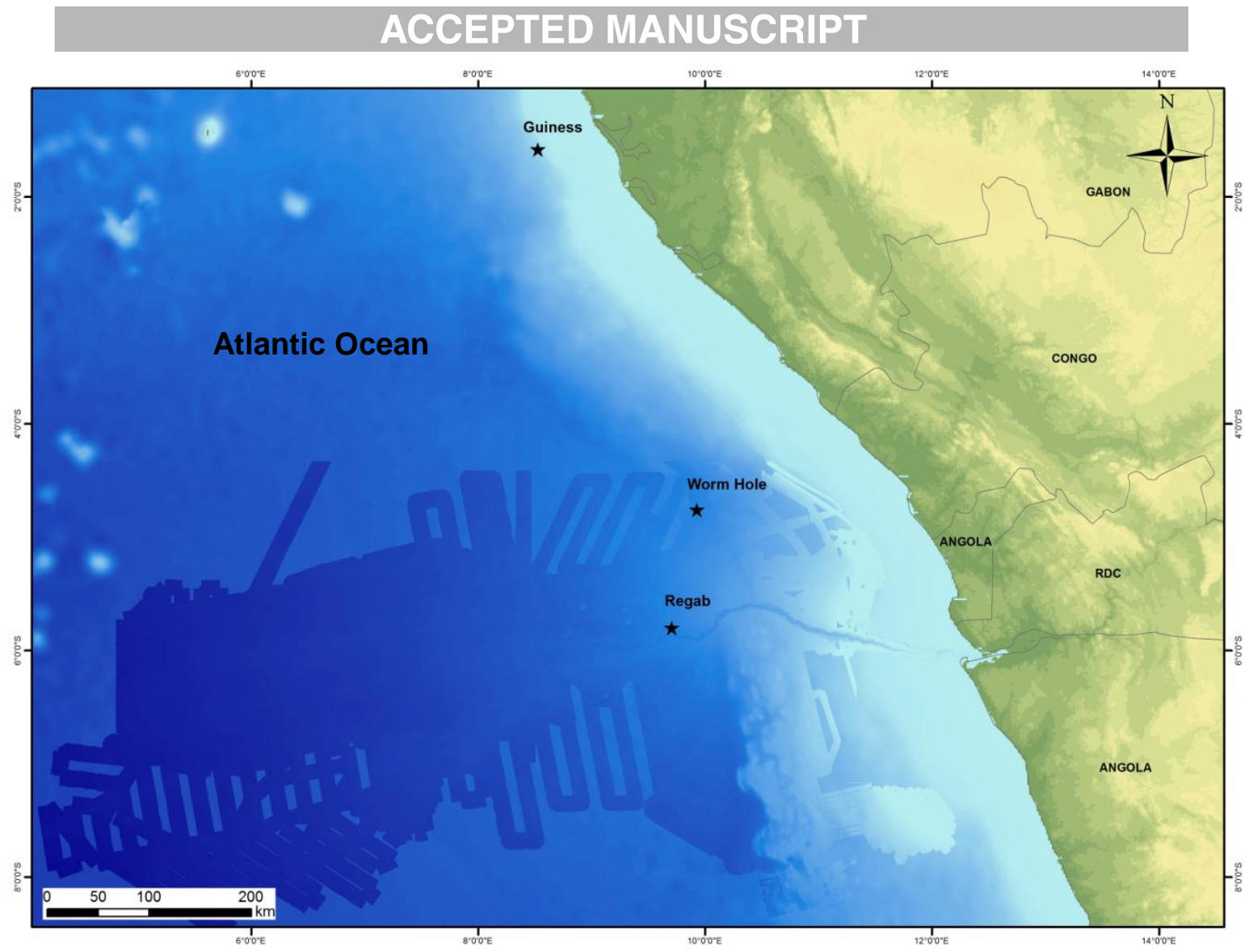

Figure 1. Pockmarks sites (asterisk) visited during the Western African Cold Seeps cruise (WACS) in February 2011 aboard the research vessel Pourquoi Pas?.

The first deep-sea polychaete species studied was Lamellibrachia sp. 'Guiness' ('temporary name') (family Siboglinidae), collected at a shallow pockmark of the Guiness area (Dive 433: $1^{\circ} 34.65^{\prime} \mathrm{S}, 8^{\circ} 32.91^{\prime} \mathrm{E}, 582 \mathrm{~m}$ depth) (Fig. 1) from a tubeworm aggregation (Fig. 2) using the ROV claw. Once on board, the worms were removed from their tube in the cold room using dissecting scissors by cutting longitudinally a piece of the tube, coupled with the use of a $5 \mathrm{ml}$ syringe to extract each worm from its tube without damaging it. Sequencing of the COI mitochondrial marker indicated that this species was new to science (S. Hourdez, unpublished data). Four specimens of Lamellibrachia sp. 'Guiness' were kept alive and transferred into individual in twice-filtered seawater (TFSW) containers in a tray on ice, to determine the sex. A hypodermic sterile syringe was used to perform biopsies into the trunk, and particularly not far away from the gonopores of both sexes posteriorly to the vestimentum. Once observed, gametes that were at an advanced stage of gametogenesis (large fully-grown primary oocytes for females and active swimming spermatozoa for males) were sampled and stored into individual Eppendorf tubes on ice until IVF experiments (see below). Some oocytes were directly fixed in $4 \%$ formaldehyde as a positive control to confirm the stage of meiosis prior 


\section{ACCEPTED MANUSCRIPT}

in vitro fertilization experiments (IVF).

One male and one female Lamellibrachia sp. 'Guiness' were fixed in Bouin's fixative for 24 hours and then rinsed and stored in $70 \%$ of ethanol at $4{ }^{\circ} \mathrm{C}$ until later used in the laboratory on land.

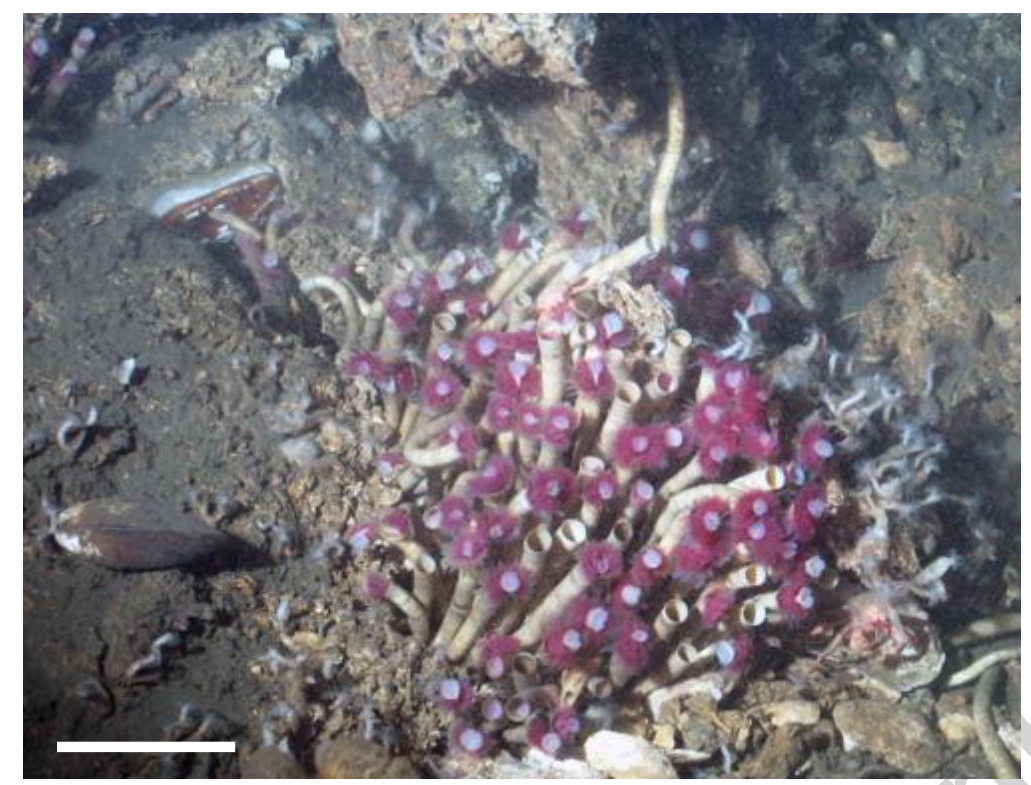

Figure 2. Photo in situ of a patch of Lamellibrachia sp. 'Guiness' (arrow). Photo credit OIFREMER, WACS2011. Scale bar is $6 \mathrm{~cm}$.

The second deep-sea polychaete species studied was the polynoid scale-worm Branchipolynoe cf. seepensis (Fig. 3) that live in commensalism inside the pallial cavity of the seep mussels Bathymodiolus aff. boomerang (one worm per mussel) was sampled several times while collecting seep mussels by the arm of the ROV. Seven scale-worms were sampled during dive 426 (05'47' $89.35 \mathrm{~S}$ and 009' 42'”62.62 E) at the Regab pockmark in dense mussel beds (sites M1 and M2) at $3153 \mathrm{~m}$ depth (Fig. 1) and six scale-worms (including one pair of male/female) were collected during the ROV dive 431 at Worm Hole (04'45',57.97 S and 009' 56'47.99 E) at $3094 \mathrm{~m}$ depth (Fig. 1). Each scale-worm was removed from the pallial cavity of the mussel and kept individually in seawater in a cold room at $6^{\circ} \mathrm{C}$. Then each individual was anesthetized with a gradient of ethanol in 1\%, 2.5\% and 5\% TFSW on 0.45 $\mu \mathrm{m}$ (Gaudron and Bentley 2002). Using a sterile hypodermic syringe, a biopsy of coelomic fluid containing the gametes was carried laterally into chaetigers placed around the $2 / 3$ posteriorly of the worm's full length, to determine the sex of the worm and the maturity stage of the gametes. When active spermatozoa and fully-grown primary oocytes were observed, 


\section{ACCEPTED MANUSCRIPT}

gametes were sampled and stored into Eppendorf tubes on ice to carry out IVF experiments (see below).

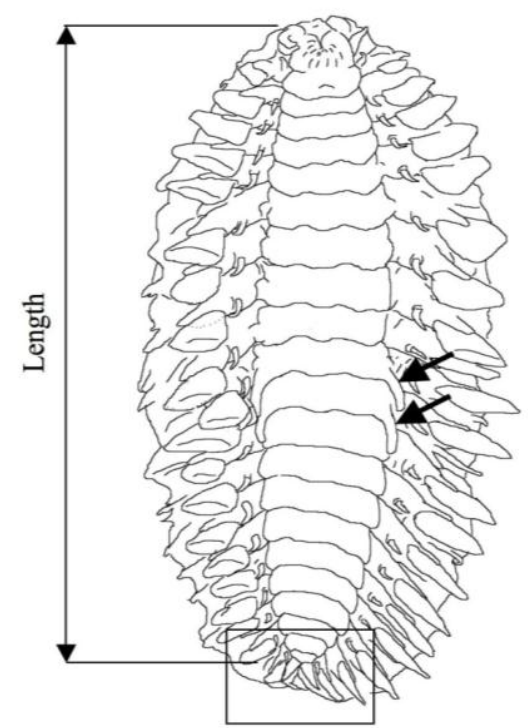

A

$1 \mathrm{~cm}$

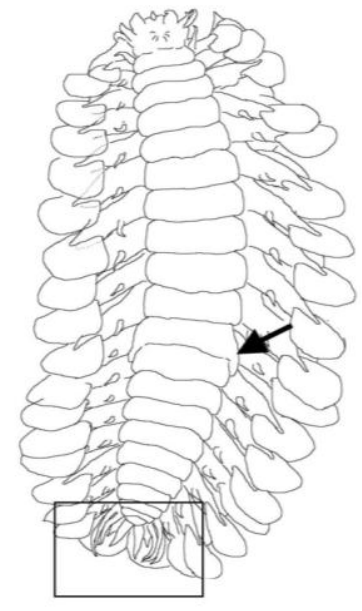

B

$0.5 \mathrm{~cm}$

Figure 3. Drawing of Branchipolynoe aff. seepensis recovered within the pallial cavity of Bathymodiolus spp. Sexual dimorphism can be seen as a difference of size, where females (A) are much larger than males (B). Second, females have two pairs of elongated nephridial papillae (or genital papillae) (two arrows) and males have one pair of genital papillae (one arrow). Finally, the boxes indicate modifications of the two posteriormost segments in males.

\subsection{Histology}

Lamellibrachia sp. 'Guiness' and Branchipolynoe cf. seepensis specimens fixed in Bouin's fixative and transferred to $70 \%$ ethanol were dehydrated in a series of ethanol of increasing concentration to $100 \%$. Tissues were then rinsed in butan-1-ol (100\%) and in Histo-Clear (EMS, USA) before embedding in paraffin wax (melting point $52^{\circ} \mathrm{C}$; Peel-A-Way, EMS, USA). Complete embedded specimens were cut into $8 \mu \mathrm{m}$-thick sections with a Jung microtome (Heidelberg, Germany), and the sections were deposited on SuperFrost Plus slides (EMS, USA). A standard Haematoxylin and Eosin (HE) staining protocol was used, and a coverslip was mounted with Permount (EMS, USA). Histological and anatomical observations were performed on an Olympus BX61 light microscope (Olympus, Japan). Oocytes diameters were measured with the ImagePro software. 


\section{3 in vitro ferilization (IVF)}

\subsection{In vitro fertilization (IVF)}

\subsubsection{Lamellibrachia sp. 'Guiness'}

Gametes (oocytes and spermatozoa) of tubeworms were mixed into a sterile microplate with TFSW and placed at $6^{\circ} \mathrm{C}$ (in situ temperature for the Guiness site), at atmospheric pressure (1 atm). Some oocytes were kept as negative control in TFSW into the sterile microplate to see if any internal fertilization had occurred. TFSW was changed daily, and subsamples of both control and fertilized oocytes were fixed in $4 \%$ formaldehyde and stored at $4{ }^{\circ} \mathrm{C}$ after $0 \mathrm{~h}, 1 \mathrm{~h}$, 3h, 5h, 7h, 9h, 14h, 21h and then $2 \mathrm{~d}, 3 \mathrm{~d}, 4 \mathrm{~d}, 5 \mathrm{~d}$ post-fertilization. The experiment was stopped at 6-d post-fertilization.

\subsubsection{Branchipolynoe cf. seepensis}

A first IVF was carried out at $8^{\circ} \mathrm{C}$ into sterile 8-well microplates with gametes from scaleworms from dive 426. Oocytes biopsied from 4 females and spermatozoa biopsied from 2 males were mixed in replicate experiments to enhance the chance of fertilization while some oocytes were kept as negative control only with TFSW. A second IVF was carried at $4{ }^{\circ} \mathrm{C}$ using the same protocol with gametes from specimens collected from dive 431 (oocytes from 3 females and spermatozoa from 1 male). TFSW was changed daily and subsamples of fertilized and negative control oocytes were fixed in $4 \%$ formaldehyde and stored at $4{ }^{\circ} \mathrm{C}$ after 0 h, 2 h, 4 h, 12 h, 24 h, 48 h and 72 h post-fertilization. All IVF were performed and maintained at atmospheric pressure (1 atm).

\subsection{Fluorescence microscopy}

Oocytes ( $n=10$ per subsample) fixed in $4 \%$ formaldehyde collected during IVF experiments, were incubated using the nucleic acid fluorescent dye Hoechst 33258 at a final concentration of $2 \mu \mathrm{g} \mathrm{ml}{ }^{-1}$ for at least one hour in the dark. Meiosis re-initiation (from Prophase I to Metaphase I) and cleavage rate were followed with an Olympus BX61 light fluorescence (365 $\mathrm{nm}$ excitation) microscope (Olympus, Japan) and captured with the ImagePro software. 


\section{ACCEPTED MANUSCRIPT}

\section{Results}

\subsection{Gametogenesis and fertilization}

\subsubsection{Lamellibrachia sp. 'Guiness'}

The general reproductive system of female Lamellibrachia sp. 'Guiness' was located within the trunk and mostly anteriorly as the rest of the trunk (most posteriorly) was filled with bacteriocytes packed with bacterial symbionts. All stages of female gametes (Fig. 4A) from germinal cells, oogonia, oocytes in vitellogenesis and fully-grown primary oocytes were identified during histological examination, suggesting 'continuous' reproduction. Packed, fully-grown primary oocytes were observed inside a mid-ventral unpaired cavity of the trunk, corresponding to an ovisac. This ovisac was observed all along the ventral side of the trunk where different stages of gametes were present on both sides of the paired ovaries (Fig. 4B). Paired oviducts with ciliated epithelia were also observed with fully-grown primary oocytes (Figs. 4C, D). A spermatheca was not found on the histological sections. This is usually a cavity that contains fully-grown primary oocytes and where clusters of spermatozoa have their heads all aligned towards the wall of the cavity (Hilário et al. 2005). However, posteriorly within the ventral ovisac filled with fully-grown primary oocytes, numerous cilia thought to belong to the epithelial cells were lining the wall (stained in pink). This wall was not stained purple with HE staining, as spermatozoa would normally do, but this could be a place to store spermatozoa. One single filiform spermatozoon was observed inside an oviduct attached to the envelope of a fully-grown primary oocyte that was still in Prophase I of meiosis (deduced from the presence of the persistence of the germinal vesicle; Fig. 4D). This single spermatozoon was composed of an elongated acrosome $(\sim 6 \mu \mathrm{m})$ attached to the envelope of a primary oocyte, of an elongated nucleus composed of a swollen apical part ( $~ 9$ $\mu \mathrm{m})$ and of an elongated posterior part $(\sim 15 \mu \mathrm{m})$, giving a total length of $\sim 24 \mu \mathrm{m}$. The flagellum was not visible in histology. This is revealing some kind of initial recognition of the spermatozoon to the oocyte envelope and its initial binding before meiosis of the primary oocyte before the fertilization process resumes. The mean fully-grown primary oocytes diameter ready to be released into the water column was $101 \mu \mathrm{m} \pm 13 \mu \mathrm{m}(n=100)$. The 'snap shot' fecundity was high, as oocytes were observed along the different sections from the posterior end of the vestimentum to further down within the trunk. In just one histological section of $8 \mu \mathrm{m}$, we estimate $\sim 700$ oocytes. 


\section{ACCEPTED MANUSCRIPT}

Regarding the male reproductive features, only germinal cells (Fig. 4E, F) spatially close to filiform spermatozoa, that were assembled in bundles (Fig. 4E), were observed. No stages of spermatogonia, spermatocytes or spermatids were observed.
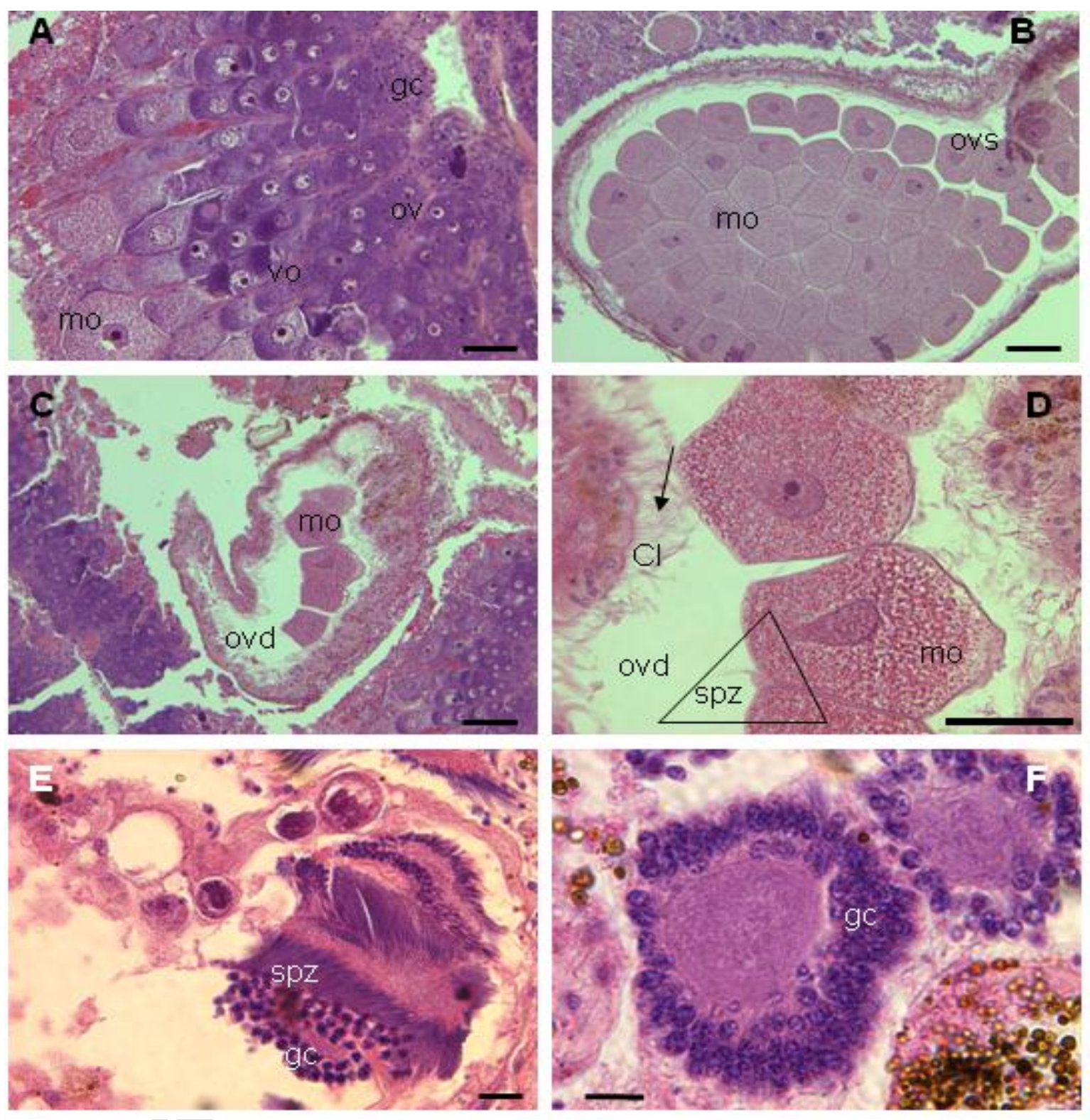

Figure 4. Hematoxilin and eosin staining of Lamellibrachia sp. 'Guiness' gonad tissues (A) Female gametes at different stages of oogenesis: germinal cells $(g c)$, oogonia (ov), vitellogenic oocytes ( $v o$ ) and fully-grown primary oocytes (mo). (B) Ovisac (ovs) filled with fully-grown primary oocytes in Prophase I of meiosis $(m o)$. (C) Oviduct (ovd) with some fully-grown primary oocytes (mo). (D) Closeup within an oviduct with a wall constituted of ciliated (arrow) epithelial cells ( $c l$ ) and the occurrence of a single spermatozoon ( $s p z)$ attached by its acrosome (triangle) to the envelope of a fully-grown primary oocyte $(m o)$. (E) Male gametes at different stages of spermatogenesis: germinal cells $(g c)$ and cluster of spermatozoa $(s p z)$. (F) Close-up of germinal cells $(g c)$. Scale bars: $50 \mu \mathrm{m}$ in (A-B); $100 \mu \mathrm{m}$ in (C); $50 \mu \mathrm{m}$ in (D); $10 \mu \mathrm{m}$ in (E-F). 


\section{ACCEPTED MANUSCRIPT}

\subsubsection{Branchipolynoe cf. seepensis}

Unfortunately all specimens fixed in Bouin's fixative were in bad condition and semi-thin sections stained with HE did not produce exploitable histological sections. As a result, no fecundity was calculated. However during biopsies of coelomic fluid, nine females and three males were identified which gave a sex ratio biased in favor of females (3:1). During observations of live specimens, all stages of oogenesis were observed in a single female suggesting 'continuous' reproduction. Large fully-grown primary oocytes indicative of lecithotrophy, were not very abundant within the 'ovisac' (mean oocyte diameters $=326 \mu \mathrm{m} \pm$ $41 \mu \mathrm{m}$, for only $n=5$ observed oocytes). Sexual dimorphism was observed, with the males having a single pair of elongated nephridial (or genital) papillae on setiger 12 and the females having two pairs of elongated nephridial (or genital) papillae on setigers 11 and 12 (Fig. 3). Females were generally larger than males (Fig. 3), but no biometric measurements were made on board before fixation. One male and female pair was recovered from the mantle cavity of a host mussel, suggesting that pairing behavior probably occurs in this species.

\subsection{In vitro fertilization and embryogenesis}

\subsubsection{Lamellibrachia sp. 'Guiness'}

The oocytes were emitted in Prophase I of meiosis (Fig. 5A) and were negatively buoyant. The spermatozoa biopsied from males were bundled, and separated after transfer to TFSW. They rapidly moved towards the oocyte envelope (Fig. 5A, B). The IVF experiment carried out at $6^{\circ} \mathrm{C}$ produced a meiotic reinitiation of Prophase I to Metaphase I after 5 h postfertilization. The first divisions appeared after $22 \mathrm{~h}$, and at $48 \mathrm{~h}$ fertilized oocytes reached the 8-cell stage (Fig. 5 C). After 5 days, the embryos reached the blastula stage. Negative control of oocytes mixed with TFSW did not show any sign of cell divisions, suggesting that there was no internal fertilization. The oocytes in this control were still in Prophase I of meiosis at the end of the experiment.

\subsubsection{Branchipolynoe cf. seepensis}

In this species, the oocytes were positively buoyant. The IVF experiments carried out at $4{ }^{\circ} \mathrm{C}$ and $8^{\circ} \mathrm{C}$ differed regarding the rate of cell division and the morphology of gametes. 


\section{ACCEPTED MANUSCRIPT}

Numerous abnormalities ( $40 \%$ of total observed oocytes) were encountered at $4{ }^{\circ} \mathrm{C}$ compared to $8^{\circ} \mathrm{C}$ ( $0 \%$ of total observed oocytes), and cleavage into a 2-cell stage was only observed after $3 \mathrm{~d}$ at $4^{\circ} \mathrm{C}$ compared to $13 \mathrm{~h}$ at $8^{\circ} \mathrm{C}$ (post-fertilization). The 4-cell stage occurred between 36 to $48 \mathrm{~h}$ at $8^{\circ} \mathrm{C}$ and 8 -cell embryo between $48 \mathrm{~h}$ to $72 \mathrm{~h}$ at $8^{\circ} \mathrm{C}$ (postfertilization). During this IVF at $8^{\circ} \mathrm{C}$, most of the oocytes from the negative control in TFSW were in Prophase I of meiosis (Fig. 5D) as with the IVF at $4^{\circ} \mathrm{C}$, but a few oocytes were already in Metaphase I of meiosis (Fig. 5E). After 4 h, these oocytes had cleaved to the embryo stage of 2-cell (Fig. 5F) suggesting some internal fertilization.
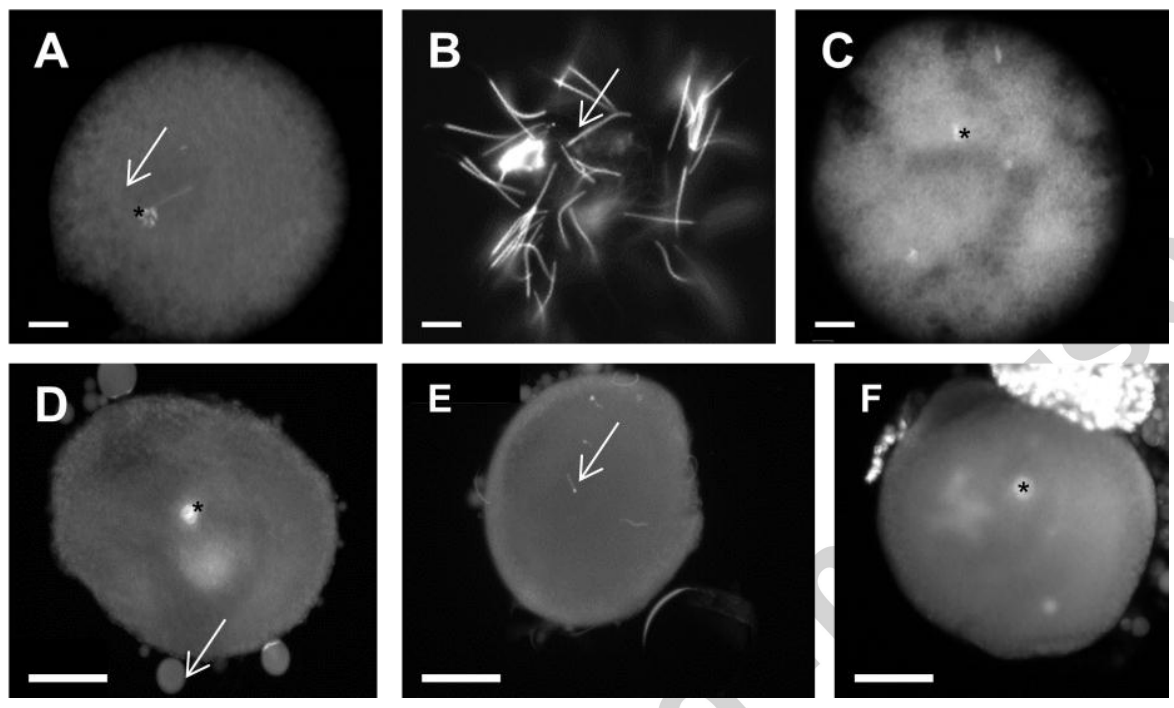

Figure 5. Fluorescence microscopic images of gametes and embryos from cold seep polychaetes stained with Hoetsch 33258 acquired with an Olympus BX61 light fluorescence microscope. A) Oocyte in Prophase I of meiois of Lamellibrachia sp. 'Guiness' female; the visible germinal vesicle delimits the nucleus (arrow); chromosomes (chrs) are highlighted (asterisk). B) Spermatozoa of Lamellibrachia sp. 'Guiness' male (arrow). C) A 8-cell embryo of Lamellibrachia sp. 'Guiness'; asterisk shows chromosomes of one of the 8 cells. D) One fully-grown primary oocyte in Prophase I of meiosis of a Branchipolynoe cf. seepensis female surrounded by very small primary oocytes (arrow). E) Oocyte in Metaphase I of meiosis of Branchipolynoe cf. seepensis female with some spermatozoa attached to the oocyte envelope (arrow). The germinal vesicle is not visible but broken down (GVBD). F) A 2-cell embryo of Branchipolynoe cf. seepensis $13 \mathrm{~h}$ post-fertilization at $8^{\circ} \mathrm{C}$; asterisk shows chrs of one of the two cells. Scale bars: $15 \mu \mathrm{m}$ in $(A-B) ; 10 \mu \mathrm{m}$ in $(C) ; 100 \mu \mathrm{m}$ in (D-F). 


\section{ACCEPTED MANUSCRIPT}

\section{Discussion}

\subsection{Adaptation of reproduction to chemosynthetic habitats}

\subsubsection{Internal fertilization}

Internal fertilization was reported in a number of species of the family Siboglinidae from vents, seeps and whale carcasses (Hilário et al. 2005; Myake et al. 2006; Katz \& Rouse 2013). In contrast to Lamellibrachia luymesi (Hilário et al. 2005) we did not find spermathecae in the coelomic cavity of Lamellibrachia sp. 'Guiness'. However, an ovisac with fully-grown primary oocytes was observed in histological sections with a wall formed by a ciliated columnar epithelium. This structure is another common feature of polychaetes from chemosynthetic habitats that had been previously reported in polynoid, alvinellid, and siboglinid families (Jouin-Toulmond 1997; Jollivet et al. 2000; Hilário 2005). In shallow water polynoid polychaetes fully-grown oocytes are generally free in the coelomic fluid and not stored in an ovisac or lead to the outside through an oviduct. We also found paired oviducts on histological sections of Lamellibrachia sp. 'Guiness'. One spermatozoon was seen attached to an oocyte envelope of one of the oviducts, suggesting possible internal fertilization. Such an anectodal spermatozoon observation of binding to fully-grown primary oocyte inside the genital tract of a female siboglinid was previously made by Gardiner and Jones (1985) in Riftia pachyptila. Hilário (2005) did observe bindings of spermatozoa to primary oocytes but this was inside the spermatheca of female reproductive system of $L$. luymesi, where it is located in the posterior end of the gonad, where the gonocoel joins the oviduct.

As previously observed in Branchipolynoe seepensis from hydrothermal vents (Jollivet et al. 2000), female B. cf. seepensis from seeps may have some anatomical features (not seen here) that are able to store mature spermatozoa (spermatheca) to ensure internal fertilization. Male $B$. cf. seepensis may transfer their spermatozoa to conspecific females via nephridial papillae during pseudo-copulation (forming pair) such as seen in the polynoid B. seepensis from hydrothermal vents (Van Dover et al. 1999; Jollivet et al. 2000). Unfortunately histological sections were of poor quality and we could not observe the spermathecae in the specimens of this study. However, some oocytes were already in Metaphase I of meiosis in the negative control at the beginning of the IVF experiments and then at the 2-cell stage after a few hours. This confirms the presence of spermatozoa stored inside the female scale-worm reproductive systems that reinitiated meiosis of the fully-grown primary oocytes, and induced cleavage 


\section{ACCEPTED MANUSCRIPT}

while in the seawater control. This strongly points to internal fertilization in this polynoid species. This supports the hypothesis of internal fertilization that was proposed by Jollivet et al. (2000) in B. seepensis from the MAR but embryogenesis does not seem to occur internally. Neither brooding embryos nor larvae were recovered from the coelomic fluid of any female polynoid in this study, an observation reported by Jollivet et al. (2000) and Daguin \& Jollivet (2005) for B. seepensis. Furthermore, a later genetic study (Plouviez et al. 2008) showed that juveniles collected inside a mussel with a large female were not related to that adult. Brooding to a very late stage is therefore unlikely, and embryos were certainly released at an early stage of development, permitting larval dispersal to nearby sites, and some local retention. It is possible that there is an early protection of the embryos until the trochophore stage. This strategy was observed in the shallow water polynoid Harmothoe imbricata for which fertilized oocytes are protected under the elytra of the females until the trochophore stage (personal observations). This was also observed for three Harmothoe species from Antarctica (Gambi et al. 2001). This, however, is not the norm in polynoids and the elytra are reduced in Branchipolynoe spp.. The general mantle cavity of the mussel could also offer a protected environment for the early development of embryos.

Overall, the two polychaete species have morphological features adapted to internal fertilization which may be an adaptation to reducing habitats that are bathed with reduced chemicals compounds, some of which, are toxic (e.g., hydrogen sulphide, $\mathrm{H}_{2} \mathrm{~S}$ ). High concentration of $\mathrm{H}_{2} \mathrm{~S}$ was measured at the Guiness site with direct $\mathrm{H}_{2} \mathrm{~S}$ fluxes from the sediment (Decker et al. 2017). Internal fertilization offers some protection to the gametes before fertilization (Eckelbarger and Young 2002). In the endemic hydrothermal vent family Alvinellidae, studies have also shown the presence of spermathecae and internal fertilization (Zal et al. 1994; Jouin-Toulmond et al. 1997). Another hypothesis emitted by Hilário et al. (2005) is that sperm storage could be an ideal strategy in deep-sea environments where periodic cues for gametogenesis and spawning timing are limited compared to shallow water environment. 


\subsubsection{Oocytes}

In Lamellibrachia sp. 'Guiness', the mean oocyte diameter $(\sim 101 \mu \mathrm{m})$ was in the range of that of several other siboglinid species from reducing habitats: Riftia pachyptila ( 80-105 $\mu \mathrm{m}$; Tyler \& Young 1999) and Ridgeia piscesae ( 85-116 $\mu \mathrm{m}$; Tyler \& Young 1999) from hydrothermal vents, and, L. luymesi ( 105 $\mu \mathrm{m}$; Tyler \& Young 1999) and L. anaximandri ( $100 \mu \mathrm{m}$; Southward et al. 2011) from cold seeps. This range of oocyte diameter is within the lower limit of oocyte size indicating lecithotrophic larvae, but the larvae could also be planktotrophic.

Oocytes are more costly to produce than spermatozoa (Bateman 1948) and natural selection may induce different strategies regarding allocation of energetic resources to male and female reproduction within species and between species. Despite being energetically costly, very large yolky oocytes like those produced by female Branchipolynoe cf. seepensis $(\sim 326 \mu \mathrm{m})$, have been observed in other polynoids from reducing habitats: B. seepensis ( $395 \mu \mathrm{m}$; Van Dover et al. 1999; Jollivet et al. 2000), Opisthotrochopodus sp. $(\sim 420 \mu \mathrm{m}$; Van Dover et al. 1999 ) and Bathykurila guaymasensis ( $220 \mu \mathrm{m}$; Glover et al. 2005). These large oocytes may permit the success of fertilization by spermatozoa. Gaudron and Bentley (2007) demonstrated the production of a sexual pheromone in the coastal polynoid Harmothoe imbricata that is released from both fully-grown primary and mature oocyte. These pheromones induce a stereotypic behaviour and subsequent pair-bond formation. To increase the chance of oocyte recognition and binding, established pairing between males and females, sperm transfer via nephridial papillae, and production of large oocytes may be favoured for fertilization success.

Large yolky eggs may promote delayed development and metabolism for longer periods of time without relying on feeding. They may therefore allow direct development (with potentially limited dispersal potential) or long planktonic lecithotrophic phases that lead to long distance dispersal. Genetic studies in the MAR B. aff. seepensis suggest that there was little local retention at the Lucky Strike vent field supporting wide dispersal potential in this species (Plouviez et al. 2008). 
Eckelbarger (2006) describes three types of spermatozoon in polychaetes. The type of spermatozoon in Lamellibrachia sp. 'Guiness' corresponds to ent-aquasperm, which is defined as a bundle of spermatozoa that come into contact with a female and is sometimes stored into a spermatheca. These spermatozoa are filiform with both an elongated acrosome and nucleus. In our study the characters of the single spermatozoon observed in the female oviduct resemble what was described by Marotta et al. (2005) for other vestimentiferan siboglinids such as L. luymesi (acrosome, $\sim 4 \mu \mathrm{m}$; nucleus, $\sim 26 \mu \mathrm{m}$ ) and Riftia pachyptila (acrosome, $\sim 6 \mu \mathrm{m}$; nucleus, $\sim 26 \mu \mathrm{m}$ ). In addition, an elongated nucleus $(>20 \mu \mathrm{m}$ ) is one of the 4 autapomorphies for the siboglinid spermatozoon (Marotta et al. 2005). In this study the flagellum in $L$. sp. 'Guiness' was not readily visible using histology compared to scanning or transmission electron microscopy. The extended length in flagellum previously measured in vestimentiferans was considered by Marotta et al. (2005) to be an adaptation to the propulsive activity of the spermatozoa along the female genital duct to reach the spermatheca found posterior to oviducts (Hilário et al. 2005). In our study, the unique autapomorphy observed in L. sp. 'Guiness' reproductive tract compared to other vestimentiferans is the presence of bundles of spermatozoa (Marotta et al. 2005).

In the polychaete family Alvinellidae, the spermatozoa are very modified, to the point that they are likely immotile and this has been considered as an autapomorphic character of the family (Zal et al. 1994; Jouin-Toulmond et al. 1997). In conclusion sperm morphology in this study of a polychaete from cold seeps support the idea that it is more correlated to phylogenetic constraints rather than adaptation to reducing habitats as suggested by previous authors (Eckelbarger \& Watling 1995; Marotta et al. 2005).

\subsubsection{Periodicity of reproduction}

The control of gametogenesis and spawning in species from shallow water ecosystems is usually controlled by a combination of the lunar cycle, the photoperiod, the temperature and sex-pheromones (Bentley and Pacey 1992; Watson et al. 2003). In deep-sea environments, environmental cues are unknown. On the MAR hydrothermal vents, both continuous and seasonal breeders live in sympatry. For instance Bathymodiolus azoricus is a seasonal breeder (Colaço et al. 2006; Dixon et al. 2006) with a periodic gametogenesis, whereas 


\section{ACCEPTED MANUSCRIPT}

Branchipolynoe seepensis is a continuous breeder (Jollivet et al. 2000). The periodicity observed in the genus Bathymodiolus was hypothesized to be linked to the pulse of organic matter available for the planktotrophic veliger larva (Tyler et al. 2007). In our study, oocytes from both the polynoid and the siboglinid species were large and rich in vitellus indicating a possible reliance on lecithotrophy rather than planktotrophy. This eliminates the need for pulse of organic matter as a possible environmental cue controlling reproduction. Another explanation of the seasonality of the breeding season of some Bathymodiolus spp. is the contribution of the particular organic matter (POM) in the mix diet of the symbiotic mussels (mixotrophic) (Riou et al. 2010) that could regulate and synchronize gametogenesis. Siboglinids are obligate symbionts and only rely on their sulphide-oxidizing bacteria for nutrition (Cordes et al. 2003). Although sometimes primary consumers (Gaudron et al. 2012), polynoids are usually active predators (Fauchald and Jumars 1979). Oocytes at all stages of development were observed in both species in our study, indicating a continuous reproduction rather than seasonal breeding.

\subsection{Contrasting embryonic development}

\subsubsection{Lamellibrachia sp. 'Guiness'}

Fertilization experiments using deep-sea organisms on board research vessels are limited due to the constraints linked with the number of cruises but also because of the timing of reproduction of the organisms. A series of invertebrates were checked for sexual maturity during the WACS cruise (mostly symbiotic bivalves and polychaetes), but only the two species of polychaetes of this study carried mature gametes and could be used to run IVF experiments on board. Lamellibrachia sp. 'Guiness' was collected late during that cruise, and its development could only be followed for a relatively short time. However, these preliminary IVF experiments provided some relevant biological information relative to lifehistory traits of cold seeps polychaetes that are still in its infancy.

Young et al. (1996) showed that the cleavage rate of embryos of two vestimentiferan species was the same at $1 \mathrm{~atm}, 50 \mathrm{~atm}$, and $100 \mathrm{~atm}$, demonstrating that pressure was not a limiting factor for relatively shallow water species of cold seeps tubeworms (500-600 m). In our study, embryonic development was also possible at atmospheric pressure, and no abnormalities of embryos were observed. For the hydrothermal vent siboglinid Riftia pachyptila (occurring at 


\section{ACCEPTED MANUSCRIPT}

about $2500 \mathrm{~m}$ depth) however pressure is important. At a pressure lower than $100 \mathrm{~atm}$ (equivalent to $1000 \mathrm{~m}$ depth), no cell division had occurred. Embryos of R. pachyptila are considered as obligate barophilic and cold stenotherm, as temperatures above $7^{\circ} \mathrm{C}$ inhibited cellular division (Brooke and Young 2009). Although pressure did not seem to impact larval development in the genus Lamellibrachia, temperature appeared to modify the development rate. Comparing our results to previous studies on embryonic development of other Lamellibrachia species at different temperatures (Fig. 6A) (Young et al. 1996; Miyake et al. 2006; this study), it seems that an increase in temperature accelerates the rate of development. The blastula stage was observed in $5 \mathrm{~d}$ at $6^{\circ} \mathrm{C}$ for Lamellibrachia sp. 'Guiness', $30 \mathrm{~h}$ at $9^{\circ} \mathrm{C}$ for L. luymesi and $14 \mathrm{~h}$ at $16^{\circ} \mathrm{C}$ for L. satsuma (Fig.6A).

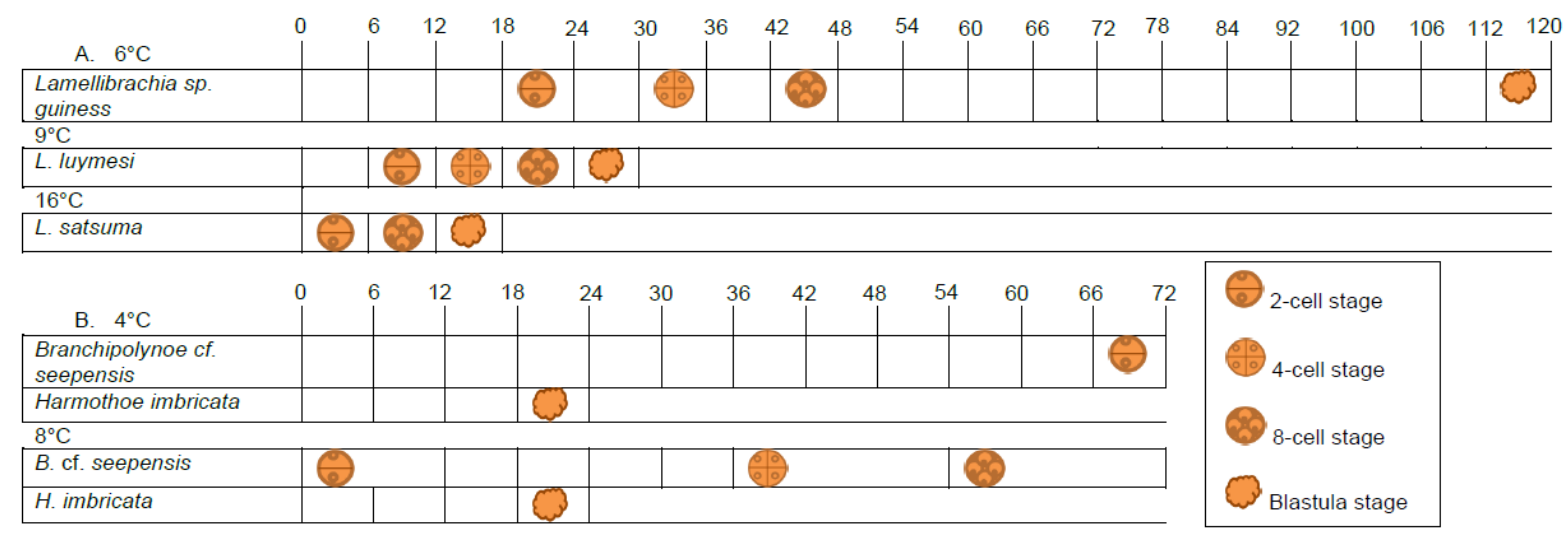

Figure 6 Comparison of embryonic development to the blastula stage of three different species of Lamellibrachia (A) and of two polynoids (B). Time is given as hours post-fertilization. (A) Data from Young et al. (1996) for Lamellibrachia luymesi, Miyake et al. (2006) for L. satsuma and our study for Lamellibrachia sp. 'Guiness'. Experiments were run at atmospheric pressure under different temperature conditions. (B) Data for the shallow water polynoid (Harmothoe imbricata) are from Gaudron (2003) and for the deep-sea polynoid (Branchipolynoe cf. seepensis) are from our study. Experiments were run at two different temperatures and at atmospheric pressure.

\subsubsection{Branchipolynoe cf. seepensis}

In vitro fertilization experiments were carried out for a deep-sea polynoid polychaete for the first time. In the shallow water polynoid Harmothoe imbricata embryos reached the blastula stage after $24 \mathrm{~h}$ at $4^{\circ} \mathrm{C}$ and $8^{\circ} \mathrm{C}$ (Gaudron 2003; Fig. 6B). This development stage was not reached after $72 \mathrm{~h}$ at both $4^{\circ} \mathrm{C}$ and $8^{\circ} \mathrm{C}$ for Branchipolynoe cf. seepensis embryos (Fig. 6B). The most advanced stage observed was the 8-cell stage for gametes fertilized and reared at 


\section{ACCEPTED MANUSCRIPT}

$8^{\circ} \mathrm{C}$. At $4^{\circ} \mathrm{C}$ (in situ Regab site temperature) it took $3 \mathrm{~d}$ to reach the 2-cell stage compared to only a few hours at $8^{\circ} \mathrm{C}$ (Fig. 6B). Again this demonstrates the slow metabolic rate and cell divisions at low temperature. In contrast to Lamellibrachia sp. 'Guiness', a number of abnormal oocytes was observed. Although not tested, pressure could have been a limiting factor. These abnormalities were very similar to those observed in embryos obtained from IVF experiments carried at atmospheric pressure with gametes biopsied from the hydrothermal vent annelid Alvinella pompejana (Pradillon et al. 2005). In this latter species, embryonic development was arrested at $2{ }^{\circ} \mathrm{C}$ (Pradillon et al. 2001) and slow rate of embryonic development was observed at $5^{\circ} \mathrm{C}$ under in situ pressure (only 2 to 16 -cell stages were obtained after $5 \mathrm{~d}$ ). With a temperature of $10^{\circ} \mathrm{C}$ and $14^{\circ} \mathrm{C}$, the 8-cell stage was reached after $3 \mathrm{~d}$ and $1 \mathrm{~d}$ respectively. Similar cleavage rate was observed in the present study for Branchipolynoe cf. seepensis at $8^{\circ} \mathrm{C}$ at 1 atm (Fig.6B).

\subsection{Consequences for larval dispersal and population connectivity}

\subsubsection{Lamellibrachia sp. 'Guiness'}

Embryos of the siboglinid Lamellibrachia spp., when released into the water column could rise and disperse into a range of different pressures conditions. This effectively allows them to use either deep water currents (usually slow; e.g. Olu-Leroy et al. 2007a) or the surface current (usually fast; e.g. Olu-Leroy et al. 2007a), for larval dispersal, thereby allowing a range of dispersal distances. In the Mediterranean, DNA corresponding to a siboglinid was collected in samples as shallow as $5 \mathrm{~m}$ depth (Marie et al. 2006). Reproduction seems continuous with a high instantaneous fecundity which favours a release of numerous propagules under different hydrological conditions throughout the year, favouring larval dispersal into potentially different directions. The collection during our cruise was the second time that the genus Lamellibrachia was recovered from the Eastern Atlantic. The species from Guiness has not yet been described but is genetically more closely related to L. anaximandri from Eastern Mediterranean (S. Hourdez, unpublished data). Larvae of Lamellibrachia spp. can colonize wood, hard bottoms near cold seeps (carbonate crusts) and vents (Dando et al. 1992; Southward et al. 2011; Rubin-Blum et al. 2014). Lamellibrachia spp. populations use these different reducing habitat types as stepping stones that maintain gene flow among population (metapopulations; Vrijenhoek 2010). Miyake et al. (2006) estimated that larvae of L. satsuma could disperse up to $2000 \mathrm{~km}$. The Mediterranean Sea, spans up to $3860 \mathrm{~km}$ from 


\section{ACCEPTED MANUSCRIPT}

East to West, separated from the Atlantic Ocean by the Strait of Gibraltar, and then subdivided West to East by the Strait of Sicily. The Straits of Gibraltar and of Sicily may not be physical barriers to larval dispersal, as larvae are pressure-tolerant (Young et al. 1996; this study). Only a biophysical model including the spawning site, spawning period, fecundity, current velocity, larval velocity and pelagic larval duration (Hilário et al. 2015) may shed light on the possible genetic exchange between different populations of Lamellibrachia spp. within the Mediterranean (Southward et al. 2011; Hilário et al. 2011; Rubin-Blum et al. 2014) and possibly others from the Eastern Atlantic such as those found accidentally by Dando et al. (1995) on a shipwreck. Young et al. (1996) have shown that larvae of Lamellibrachia luymesi were lecithotrophic, relying on its maternal reserve. In cold water the larvae consume less energy and this type of development will extend their PLD, which may improve the larval dispersal kernel for this species.

\subsubsection{Branchipolynoe cf. seepensis}

The very large size of oocytes of Branchipolynoe cf. seepensis suggests either lecithotrophic larvae or direct development, with possible offspring-caring behaviour by the parent.

However, parental care is costly for the parent and it is probably not advantageous in reducing habitats. These habitats are indeed fragmented and ephemeral, and a good dispersal capacity is paramount to colonizing new sites. Genetic studies on the MAR hydrothermal vent $B$. aff. seepensis showed some possible local retention but also some wider dispersal (Daguin and Jollivet 2005; Plouviez et al. 2008). In particular, juveniles found in the same mussel as a large female were not related to that adult (Plouviez et al. 2008). Embryos of the polynoid $B$. cf. seepensis when released, may rise in the water column until a minimal pressure threshold is reached, as this seems to be a limiting factor in its embryonic development. However, development rate (cell division) seems higher at $8^{\circ} \mathrm{C}$ than $4^{\circ} \mathrm{C}$ and does not exclude some ontogenetic migration until a given depth (where a higher temperature is encountered). Such a scenario has been hypothesized by Pradillon et al. (2005) for the hydrothermal vent annelid Alvinella pompejana embryos. Low temperatures do not inhibit cell division, but slow down development, until a minimal temperature threshold $\left(2^{\circ} \mathrm{C}\right)$ where embryogenesis was arrested (Pradillon et al. 2001). Polynoid embryos that were positively buoyant may passively use the deep-sea cold water for larval dispersal. In our study and in other hydrothermal vent species, females carry oocytes at different stages and likely release batches of oocytes several times during the year favouring different dispersal pathways, as currents can change seasonally. The large size of the lecithotrophic embryos and larvae provides a large energy reserve in 


\section{ACCEPTED MANUSCRIPT}

oligotrophic waters for a long pelagic larval dispersal, combined with a slow metabolism at low temperature (extending the PLD).

As mentioned before for Lamellibrachia spp., it would be interesting to run a biophysical model to see possible genetic exchange that may exist between the different populations of $B$. cf. seepensis from this study sampled in cold seeps in the Western Africa continental margin with those from hydrothermal vent field from the MAR.

\section{Conclusions}

The two seep polychaetes we studied share some reproductive features that have also been observed in other species from chemosynthetic habitats. The females of both species exhibit evidence for internal fertilization, and continuous reproduction. Low temperature decreases the rate of cell division, and is likely linked to a reduced metabolic rate. This may be advantageous for both species to extend their PLD. Lamellibrachia sp. 'Guiness' embryos are pressure-tolerant, which can allow the embryos and larvae to disperse at a range of depths using different water currents and colonize diverse chemosynthetic habitats (organic substrates (including sunken wood and mammal carcasses), vents and seeps). Branchipolynoe cf. seepensis embryos appear to be sensitive to low pressure, at least at the beginning of their development. This may therefore limit the dispersal of the species, in particular because deep currents are significantly slower than surface currents. Some of the reproductive features here support either adaptation to reducing habitats (e.g. internal fertilization) or phylogenetic constraints (e.g. elongated nucleus). Both reproduction and development data may be used for dispersal biophysical models in the future to help better understand the connectivity of metapopulations of these species.

\section{Acknowlegements}

We thank the captain, pilots and crew of RV Pourquoi Pas? And ROV Victor 6000 during the WACS cruise (chief scientist K. Olu). The research was funded by UPMC and CNRS. We thank Jozée Sarrazin who found this patch of beautiful Lamellibrachia sp. 'Guiness' during her shift. We are grateful to the people in charge of the Olympus BX61 light fluorescence 


\section{ACCEPTED MANUSCRIPT}

microscope from the UMR 7138 who kindly let us using it. We thank Constance Boitard for her help with the visualization of polynoid embryos using the Fluorescence Microscope.

\section{Declaration of interest}

All authors declare that they have no conflict of interest. All applicable international, national, and/or institutional guidelines for the care and use of animals were followed.

\section{References}

Andersen, A.C., Hourdez, S., Marie, B., Jollivet, D., Lallier, F.H., Sibuet, M., 2004. Escarpia southwardae sp. nov., a new species of vestimentiferan tubeworm (Annelida, Siboglinidae) from West African cold seeps. Canadian Journal of Zoology 82, 980-999.

Bateman, A.J., 1948. Intrasexual selection in Drosophila. Heredity 2, 349-368.

Bentley, M.G., Pacey, A.A., 1992. Physiological and environmental control of reproduction in polychaetes. Oceanography and Marine Biology 30, 443-481.

Bergquist, D.C., Eckner, J.T., Urcuyo, I.A., Cordes, E.E., Hourdez, S., Macko, S.A., Fisher, C.R., 2007. Using stable isotopes and quantitative community characteristics to determine a local hydrothermal vent food web. Marine Ecology Progress Series 330, 49-65.

Bright, M., Lallier, F.H., 2010. The biology of Vestimentiferan tubeworms. Oceanography and marine biology: an annual review 48, 213-265.

Britayev, T.A., Martin, D., Krylova, E.M., von Cosel, R., Aksiuk, T.S., 2007. Life-history traits of the symbiotic scale-worm Branchipolynoe seepensis and its relationships with host mussels of the genus Bathymodiolus from hydrothermal vents. Marine Ecology 28, 36-48. Brooke, S.D., Young, C.M., 2009. Where do the embryos of Riftia pachyptila develop? Pressure tolerances, temperature tolerances, and buoyancy during prolonged embryonic dispersal. Deep Sea Research Part II: Topical Studies in Oceanography 56, 1599-1606.

Colaço, A., Martins, I., Laranjo, M., Pires, L., Leal, C., Prieto, C., Costa, V., Lopes, H., Rosa, D., Dando, P.R., Serrão-Santos, R., 2006. Annual spawning of the hydrothermal vent mussel, Bathymodiolus azoricus, under controlled aquarium, conditions at atmospheric pressure. Journal of Experimental Marine Biology and Ecology 333, 166-171. 


\section{ACCEPTED MANUSCRIPT}

Cordes, E.E., Bergquist, D.C., Shea, K., Fisher, C.R., 2003. Hydrogen sulphide demand of long-lived vestimentiferan tube worm aggregations modifies the chemical environment at deep-sea hydrocarbon seeps. Ecology Letters 6, 212-219.

Cosel, R. von, Olu, K., 1998. Gigantism in Mytilidae. A new Bathymodiolus from cold seep areas on the Barbados accretionary Prism. Comptes Rendus de l'Académie des Sciences de Paris, Série II 321, 655-663.

Cowen, R.K., Sponaugle, S., 2009. Larval dispersal and marine population connectivity. Annual Review of Marine Science 1, 443-466.

Daguin, C., Jollivet, D., 2005. Development and cross-amplification of nine polymorphic microsatellite markers in the deep-sea hydrothermal vent polychaete Branchipolynoe seepensis. Molecular Ecology 5, 780-783.

Dando, P.R., Southward, A.J., Southward, E.C., Dixon, D.R., Crawford, A., Crawford, M., 1992. Shipwreck tube worm. Nature 356, 667.

Decker, C., Zorn, N., Le Bruchec, J., Caprais, J.C., Potier, N., Leize-Wagner, E., Lallier, F., Olu, K., Andersen, A., 2017. Can hemoglobin characteristics of vesicomyid clam species influence their distribution in deep-sea sulfide-rich sediments? A case study in the Gulf of Guinea. Deep Sea Research part II: Topical Studies in Oceanography 142, 219-232.

Dixon, D.R., Lowe, D.M., Miller, P.I., Villemin, G.R., Colaço, A., Serrão-Santos, R., Dixon, L.R., 2006. Evidence of seasonal reproduction in the Atlantic vent mussel Bathymodiolus azoricus, and an apparent link with the timing of photosynthetic primary production. Journal of the Marine Biological Association of the UK 86, 1363.

Duperron, S., Rodrigues, C. F., Léger, N., Szafranski, K., Decker, C., Olu, K., Gaudron, S.M., 2012. Diversity of symbioses between chemosynthetic bacteria and metazoans at the Guiness cold seep site (Gulf of Guinea, West Africa). MicrobiologyOpen 1(4), 467-480.

Eckelbarger, K.J., Young, C.M., 2002. Spermiogenesis and modified sperm morphology in "seepworm" Methanoaricia dendrobranchiata (Polychaeta: Orbiniidae) from a methane seep environment in the Gulf of Mexico: implications for fertilization biology. Biological Bulletin203, 134-143.

Eckelbarger, K.J., Young, C.M., Llodra, E.R., Brooke, S., Tyler, P., 2001. Gametogenesis, spawning behavior, and early development in the "iceworm" Hesiocaeca methanicola (Polychaeta: Hesionidae) from methane hydrates in the Gulf of Mexico. Marine Biology 138, $761-775$. 


\section{ACCEPTED MANUSCRIPT}

Eckelbarger, K.J., Watling, L. 1995. Role of phylogenetic constraints in determining reproductive patterns in deep-sea invertebrates. Invertebrate Biology 114, 256-265.

Fauchald, K., Jumars, P.A., 1979. The diet of worms: a study of polychaete feeding guilds. Oceanogr. Marine Biology Annual Review 17, 193-284.

Gambi, M.C., Patti, F.P., Micaletto, G., Giangrande, A., 2001. Diversity of reproductive features in some Antarctic polynoid and sabellid polychaetes, with a description of Demonax polarsterni sp. n. (Polychaeta, Sabellidae). Polarar Biology 24, 883-891.

Gardiner, S.L., Jones, M.L., 1985. Ultrastructure of spermiogenesis in the vestimentiferan tubeworm Riftia pachyptila (Pogonophora: Obturata). Transactions of the American Microscopical Society 104, 19-44.

Gaudron, S.M., Lefebvre, S., Nunes Jorge, A., Gaill, F., Pradillon, F., 2012. Spatial and temporal variations in food web structure from newly-opened habitat at hydrothermal vents. Marine Environmental Research 77, 129-140.

Gaudron, S.M., Bentley, M.G., 2007. Chemical signal inducing pairing in marine polychaete Harmothoë imbricata. Journal of Marine Biology Association UK 87, 1115-1116.

Gaudron, S.M., 2003. Environment-endocrine-pheromone relationships in the control of reproduction in the scale worm Harmothoë imbricata (Polychaeta: Polynoidae) (L.). Ph. D Thesis, University of Newcastle-upon-Tyne, UK, 199pp.

Gaudron, S.M., Bentley, M.G., 2002. Control of reproductive behaviour in the scale worm Harmothoë imbricata (Annelida: Polychaeta: Polynoidae). Invertebrate Reproduction Development 41 (1-3), 109-118.

Glover, A.G., Goetze, E., Dahlgren, T.G., Smith, C.R., 2005. Morphology, reproductive biology and genetic structure of the whale-fall and hydrothermal vent specialist, Bathykurila guaymasensis Pettibone, 1989 (Annelida: Polynoidae). Marine Ecology 26, 223-234.

Govenar, B., 2010. Shaping vent and seep communities: habitat provision and modification by foundation species. In: Kiel, S. (Ed.), The Vent and Seep Biota, 403-432.

Hilário, A., Metaxas, A., Gaudron, S.M., Howell, K.L., Mercier, A., Mestre, N.C., Ross, R.E., Thurnherr, A.M., Young, C., 2015. Estimating dispersal distance in the deep sea: challenges and applications to marine reserves. Frontiers in Marine Science 2, 1-14.

Hilário, A., Comas, M.C., Azevedo, L., Pinheiro, L., Ivanov, M.K., Cunha, M.R., 2011. First record of a Vestimentifera (Polychaeta: Siboglinidae) from chemosynthetic habitats in the 


\section{ACCEPTED MANUSCRIPT}

western Mediterranean Sea Biogeographical implications and future exploration. Deep-Sea Research Part I 50, 200-207.

Hilário, A., 2005. Reproductive ecology of Vestimentifera (Polychaeta: Siboglinidae) from hydrothermal vents and cold seeps. PhD Thesis, University of Southampton, 113pp.

Hilário, A., Young, C.M., Tyler, P.A., 2005. Sperm storage, internal fertilization, and embryonic dispersal in vent and seep tubeworms (Polychaeta: Siboglinidae: Vestimentifera). The Biological Bulletin 208, 20-28.

Jollivet, D., Empis, A., Baker, M.C., Hourdez, S., Comtet, T., Jouin-Toulmond, C., Desbruyères, D., Tyler, P.A., 2000. Reproductive biology, sexual dimorphism, and population structure of the deep sea hydrothermal vent scale-worm, Branchipolynoe seepensis (Polychaeta: Polynoidae). Journal of the Marine Biological Association of the United Kingdom 80, 55-68.

Jouin-Toulmond, C., Zal, F.D., Hourdez, S., 1997. Genital apparatus and ultrastructure of the spermatozoa in Alvinella pompejana (Annelida: Polychaeta). Cahiers de Biologie Marine 38, $128-129$.

Katz, S., Rouse, G.W., 2013. The reproductive system of Osedax (Annelida, Siboglinidae): ovary structure, sperm ultrastructure, and fertilization mode. Invertebrate Biology 132, 368 385 .

Levesque, C., Kim Juniper, S., Limén, H., 2006. Spatial organization of food webs along habitat gradients at deep-sea hydrothermal vents on Axial Volcano, Northeast Pacific. Deep Sea Research Part I: Oceanographic Research Papers 53, 726-739.

Marie, D., Zhu, F., Balagué, V., Ras, J., Vaulot, D., 2006. Eukaryotic picoplankton communities of the Mediterranean Sea in summer assessed by molecular approaches (DGGE, TTGE, QPCR). FEMS Microbiology Ecology 55, 403-415.

Marotta, R., Melone, G., Bright, M., Ferraguti, M., 2005. Spermatozoa and sperm aggregates in the vestimentiferan Lamellibrachia luymesi compared with those of Riftia pachyptila (Polychaeta: Siboglinidae: Vestimentifera). The Biological Bulletin 209, 215-226.

Marsh, A.G., Mullineaux, L., Young, C.M., Manahan, D., 2001. Larval dispersal potential of the tubeworm Riftia pachyptila at deep-sea hydrothermal vents. Nature 411, 77-80.

Miyake, H., Tsukahara, J., Hashimoto, J., Uematsu, K., Maruyama, T., 2006. Rearing and observation methods of vestimentiferan tubeworm and its early development at atmospheric pressure, in: Felbeck, H. et al. (Ed.) Third International Symposium on Hydrothermal Vent 


\section{ACCEPTED MANUSCRIPT}

and Seep Biology, La Jolla, USA, September 12-16, 2005. Cahiers de Biologie Marine, 47(4), $471-475$.

Mullineaux, L.S., McGillicuddy, D.J., Mills, S.W., Kosnyrev, V.K., Thurnherr, A.M., Ledwell, J.R., Lavelle, J.W., 2013. Active positioning of vent larvae at a mid-ocean ridge. Deep Sea Research Part II: Topical Studies in Oceanography 92, 46-57.

Mullineaux, L.S., Peterson, C.H., Micheli, F., Mills, S.W., 2003. Successional mechanism varies along a gradient in hydrothermal fluid flux at deep-sea vents. Ecological Monographs 73 (4), 523-542.

Olu, K., 2011. WACS cruise, R/V Pourquoi Pas?. http://dx.doi.org/10.17600/11030010.

Olu-Le Roy, K., Cosel, R. von, Hourdez, S., Carney, S.L., Jollivet, D., 2007a. Amphi-Atlantic cold-seep Bathymodiolus species complexes across the equatorial belt. Deep Sea Research Part I: Oceanographic Research Papers 54, 1890-1911.

Olu-Le Roy, K., Caprais, J.C., Fifis , A., Fabri , M.C., Galéron, J., Budzinski, H., Le Ménach, K., Khripounoff, A., Ondréas, H., Sibuet, M., 2007b. Cold seep assemblages on a giant pockmark off West Africa: spatial patterns and environmental control. Marine Ecology 28, $115-130$.

Ondréas, H., Olu, K., Fouquet, Y., Charlou, J., Gay, A., Dennielou, B., Donval, J., Fifis, A., Nadalig, T., Cochonat, P., Cauquil, E., Bourillet, J., Moigne, M., Sibuet, M., 2005. ROV study of a giant pockmark on the Gabon continental margin. Geo-Marine Letters 25, 281.

Plouviez, S., Daguin-Thiébaut, C., Hourdez, S., Jollivet, D., 2008. Juvenile and adult scale worms Branchipolynoe seepensis in Lucky Strike hydrothermal vent mussels are genetically unrelated. Aquatic Biology 3, 79-87.

Pierre, C., Fouquet, Y., 2007. Authigenic carbonates from methane seeps of the Congo deepsea fan. Geo-Marine Letters 27, 249-257.

Pradillon, F., Le Bris, N., Shillito, B., Young, C.M., Gaill, F., 2005. Influence of environmental conditions on early development of the hydrothermal vent polychaete Alvinella pompejana. The Journal of Experimental Biology 208, 1551-1561.

Pradillon, F., Shillito, B., Young, C.M., Gaill, F., 2001. Deep sea ecology - developmental arrest in vent worm embryos. Nature 413, 6857. 


\section{ACCEPTED MANUSCRIPT}

Ramirez-Llodra, E., Tyler, P.A., Baker, M.C., Bergstad, O.A., Clark, M.R., Escobar, E., Levin, L.A., Menot, L., Rowden, A.A., Smith, C.R., Dover, C.L.V., 2011. Man and the Last Great Wilderness: Human Impact on the Deep Sea. Plos One 6, e22588.

Ritt, B., Pierre, C., Gauthier, O., Wenzhöfer, F., Boetius, A., Sarrazin, J., 2011. Diversity and distribution of cold-seep fauna associated with different geological and environmental settings at mud volcanoes and pockmarks of the Nile Deep-Sea Fan. Marine Biology 158, 1187-1210.

Riou, V., Duperron, S., Halary, S., Dehairs, F., Bouillon, S., Martins, I., Colaço, A., Santos, R.S., 2010. Variation in physiological indicators in Bathymodiolus azoricus (Bivalvia: Mytilidae) at the Menez Gwen Mid-Atlantic Ridge deep-sea hydrothermal vent site within a year. Marine Environmental Research 70, 264-271.

Rubin-Blum, M., Tsadok, R., Shemesh, E., Goodman-Tchernov, B.N., Austin, J.A., Coleman, D.F., Ben-Avraham, Z., Gruber, D.F., Tchernov, D., 2014. Distribution of the Lamellibrachia spp. (Siboglinidae, Annelida) and their trophosome endosymbiont phylotypes in the Mediterranean Sea. Marine Biology 161, 1229-1239.

Sahling, H., Bohrmann, G., Spiess, V., Bialas, J., Breitzke, M., Ivanov, M., Kasten, S., Krastel, S., Schneider, R., 2008. Pockmarks in the Northern Congo Fan area, SW Africa: Complex seafloor features shaped by fluid flow. Marine Geology 249, 206-225.

Southward, E.C., Andersen, A.C., Hourdez, S., 2011. Lamellibrachia anaximandri n. sp., a new vestimentiferan tubeworm (Annelida) from the Mediterranean, with notes on frenulate tubeworms from the same habitat. Zoosystema 33, 245-279.

Thurber, A.R., Sweetman, A.K., Narayanaswamy, B.E., Jones, D.O.B., Ingels, J., Hansman, R.L., 2014. Ecosystem function and services provided by the deep sea. Biogeosciences 11, 3941-3963.

Tyler, P.A., Young, C.M., 1999. Reproduction and dispersal at vents and cold seeps. Journal of The Marine Biology Association of The United Kingdom 79, 193-208.

Tyler, P., Young, C.M., Dolan, E., Arellano, S.M., Brooke, S.D., Baker, M., 2007. Gametogenic periodicity in the chemosynthetic cold-seep mussel "Bathymodiolus" childressi. Marine Biology 150, 829-840.

Van Dover, C.L., Trask, J., Gross, J., Knowlton, A., 1999. Reproductive biology of free-living and commensal polynoid polychaetes at the Lucky Strike hydrothermal vent field (MidAtlantic Ridge). Marine Ecology Progress Series 181, 201-214. 


\section{ACCEPTED MANUSCRIPT}

Vrijenhoek, R.C., 2010. Genetic diversity and connectivity of deep-sea hydrothermal vent metapopulations. Molecular Ecology 19, 4391-4411.

Watson, G.J., Bentley, M.G, Gaudron, S.M., Hardege, J., 2003. The role of chemical signals in the spawning induction of polychaete worms and other marine invertebrates. Journal of Experimental Marine Biology and Ecology 294, 169-187.

Young, C.M., He, R., Emlet, R.B., Li, Y., Qian, H., Arellano, S.M., Van Gaest, A., Bennett, K.C., Wolf, M., Smart, T.I., Rice, M.E., 2012. Dispersal of Deep-Sea Larvae from the IntraAmerican Seas: Simulations of Trajectories using Ocean Models. Integrative and Comparative Biology 52, 483-496.

Young, C.M., 2003. Reproduction, development and life-history traits. In: Tyler, P.A. (ed) Ecosystems of the deep oceans. Elsevier, Amsterdam, 381-426.

Young, C.M., Vázquez, E., Metaxas, A., Tyler, P.A., 1996. Embryology of Vestimentiferan tube worms from deep-sea methane/sulphide seeps. Nature 381, 514-516.

Zal, F.D., Desbruyères, D., Jouin-Toulmond, C., 1994. Sexual dimorphism in Paralvinella grasslei, a polychaete annelid from deep-sea hydrothermal vents. Comptes Rendus de l’Académie des Sciences, Série C 317, 42-48.

Highlights

-Reproduction and development of a new species Lamellibrachia sp. 'Guiness', a deep-sea cold seeps polychaete was investigated.

-Reproduction and development of a population of Branchipolynoe cf. seepensis was investigated in a deep-sea cold seeps.

-For the first time an in vitro fertilization experiment was carried out on gametes for a deepsea polynoid species.

-Lamellibrachia sp. 'Guiness' embryos are pressure-tolerant. 